\title{
THE EFFECT OF TASK COMPLEXITY AND TASK CONDITIONS ON FOREIGN LANGUAGE DEVELOPMENT AND PERFORMANCE. THREE EMPIRICAL STUDIES.
}

\author{
Lies Sercu \\ Lieve De Wachter \\ Elke Peters \\ Katholieke Universiteit Leuven \\ Folkert Kuiken \\ Ineke Vedder \\ Universiteit Amsterdam
}

\begin{abstract}
It has been argued that tasks constitute a valid alternative unit to sequence the language learning process, as opposed to linguistically defined syllabuses. Implementing this claim presupposes that it is possible to assess the cognitive and linguistic demands of tasks, so that they can be sequenced in such a way that they optimally support and promote the L2 learning process. Knowing what demands a task will make opens up the possibility of using task design to manipulate the learner's attention between form and meaning in ways that may help interlanguage development.

In this article, we present three empirical studies, which have tried to manipulate task complexity in order to study the effects of differing levels of task complexity on (L2) performance. We situate our studies within the Triadic Componential Framework for Task Design (TCFTD), elaborated by Robinson (1995; 2001; 2005) and interpret our findings in the light of two alternative theories, trying to explain effects on $L 2$ performance arising from task manipulation, namely the Limited Attentional Capacity Model (Skehan \& Foster 2001), and the Cognition Hypothesis (Robinson 2001; 2005). Apart from yielding evidence against or in favour of these theories, our studies demonstrate that manipulating L2 learners' attention while performing a task is anything but straightforward. The studies also illustrate how task conditions appear to interact with task complexity.
\end{abstract}


The effect of task complexity and task conditions on foreign language development and performance. Three empirical studies.

\section{Introduction}

Researchers such as Long, Robinson, Doughty, Williams, R. Ellis, or P. Skehan (to name just these) have argued that tasks are a valid alternative unit to sequence the language learning process as opposed to linguistically defined syllabuses. In a task-based syllabus, "pedagogic tasks should be developed and sequenced to increasingly approximate the demands of realworld target tasks, with the goal of enabling L2 users to succeed in attaining needed lifetime performance objectives" (Robinson, 2005: 1). In a task-based syllabus, the focus will be primarily on meaning, not on linguistic form.

Whereas in the heydays of task-based teaching, it was hoped that this strong, almost exclusive focus on meaning without (much) explicit focus on form could promote functional and communicative foreign language development, there now is a general consensus in the field of SLA research that instruction, also task-based instruction, is most beneficial to interlanguage development when it incorporates a task-induced focus on meaning and form (FonF) or an explicit, not necessarily task-induced, focus on forms, i.e. on formal linguistic aspects of the input (FonFS) (Spada, 1997; Long \& Robinson, 1998). Although both approaches have been shown to be effective (Norris \& Ortega, 2000), FonFS approaches are more obtrusive, interrupting the flow of communication.

Far more controversial is the way in which tasks should be sequenced. For, if linguistic progression, from easy and widely applicable rules to complex and less widely applicable ones, can no longer be the principle underlying syllabus design, what then can that principle be? What characteristics of tasks can be used to determine which tasks should be offered to learners first, and which tasks should be postponed until later? Being able to assess the cognitive and linguistic demands of a task makes it possible to match the learner's level of development and the task. Being able to assess a task's difficulty is crucial to understanding how it might be performed, and whether learners will have sufficient cognitive capacity left to focus on both meaning and linguistic form. Assessing the demands a task makes on learners' social and emotional skills will equally contribute to adequate task selection in the classroom. Knowing what demands a task will make opens up the possibility of using task design to manipulate the learner's attention between form and meaning in ways that may help interlanguage development.

In this article we present three empirical studies that have tried to manipulate task complexity in order to study the effects of different levels of task complexity on learners' performance. In the studies by Sercu \& De Wachter and Peters, performance was defined in terms of the retention of vocabulary and cultural information from a written text, with the second study using input enhancement and the first not. In the study by Kuiken \& Vedder, performance was operationalised in terms of the linguistic accuracy and complexity of a written text, and in terms of the richness of the vocabulary used. 
Before presenting the design and main findings of each study, we will first discuss how we operationalised task complexity, departing from the Triadic Componential Framework for L2 Task Design (TCFTD) (Robinson, 1995, 2005). From this discussion, it will become clear that we defined task complexity in terms of a task's intrinsic cognitive load and thus in terms of the demands tasks make on learners' cognitive capacity. Next, we will present two theories that have been proposed to explain learner performance in relation to task complexity, namely the Limited Attentional Capacity Model (Skehan \& Foster, 2001) and the Cognition Hypothesis (Robinson, 2001, 2005). We will explain what predictions concerning the effect of increasing task complexity arise from these theories, both with regard to developmental tasks, which aim to promote intake and retention, and thus interlanguage development, and performativity tasks, which aim to promote more automatic access to the acquired language knowledge base. In our concluding section, we will discuss our results in the light of these theories.

\section{Task complexity, task difficulty, task conditions}

Several frameworks have been proposed for task classification and design in SLA (Skehan \& Foster, 2001; Robinson, 1995, 2005). In his Triadic Componential Framework for L2 Task Design (see Figure 1 below), Robinson (1995, 2001, 2005) distinguishes the cognitive demands of tasks, contributing to differences in tasks' intrinsic complexity, from task conditions and perceived task difficulty. Whereas task conditions are specified in terms of the informationflow in classroom participation (e.g., one- versus two-way tasks) and in terms of grouping of participants (e.g., same versus different gender), task difficulty refers to learner perceptions of the level of difficulty of a task, resulting from the abilities they bring to the task (e.g., intelligence, working memory capacity) as well as their affective responses (e.g., motivation, self-efficacy).

Figure 1: Triadic Componential Framework for L2 Task Design

\begin{tabular}{|c|c|c|}
\hline $\begin{array}{l}\text { Task complexity } \\
\text { (cognitive factors) }\end{array}$ & $\begin{array}{l}\text { Task conditions } \\
\text { (interactional factors) }\end{array}$ & $\begin{array}{l}\text { Task difficulty } \\
\text { (learner factors) }\end{array}$ \\
\hline $\begin{array}{l}\text { (a) resource-directing } \\
\text { e.g., } \\
+/ \text { - few elements } \\
+/ \text { - here-and-now } \\
\text { +/- reasoning demands } \\
\text { (b) resource-dispersing } \\
\text { e.g., } \\
+/ \text { - planning } \\
+/ \text { - single task } \\
+/ \text { - prior knowledge (linguistic and other) }\end{array}$ & $\begin{array}{l}\text { (a) participation variables } \\
\text { e.g., } \\
\text { open/closed } \\
\text { one-way/two-way } \\
\text { convergent/divergent } \\
\text { (b) participant variables } \\
\text { e.g., } \\
\text { same/different gender } \\
\text { familiar/unfamiliar } \\
\text { power/solidarity }\end{array}$ & $\begin{array}{l}\text { (a) affective variables } \\
\text { e.g., } \\
\text { motivation } \\
\text { anxiety } \\
\text { confidence } \\
\text { (b) ability variables } \\
\text { e.g., } \\
\text { working memory } \\
\text { intelligence } \\
\text { aptitude }\end{array}$ \\
\hline Sequencing criteria & \multicolumn{2}{|c|}{ Methodological influences } \\
\hline $\begin{array}{l}\text { Prospective decisions about task units; } \\
\text { inherent characteristics }\end{array}$ & \multicolumn{2}{|c|}{ On-line decisions about pairs and groups } \\
\hline
\end{tabular}


The effect of task complexity and task conditions on foreign language development and performance. Three empirical studies.

A few examples will clarify how inherent characteristics can make a task easier or more difficult. The on-line processing demands of solving a riddle or a jigsaw whodunit, for example, are likely to consume considerable attention while the task is being done, requiring the speaker to establish relationships, to justify beliefs and to support interpretations of events by giving reasons, whereas the processing demands of recounting a simple story are likely to be far less (+/- few elements; +/- reasoning demands). A task that requires learners to talk about a familiar aspect of their own lives will put fewer demands on the learners' cognitive attentional resources than a task that requires learners to talk about something abstract, distant, or imaginary (+/- here-and-now). Also, taking planning time away or asking learners to perform two tasks simultaneously (e.g. listen to a complex telephone conversation in one's mother tongue and summarise its contents in the foreign language for a friend) will be more demanding or complex, cognitively speaking.

Whereas task complexity is related foremost to intralearner variability in L2 performance, task difficulty (third column in Figure 1) accounts for interlearner variability, i.e. differences between learners when they perform the task. Keeping a task's intrinsic level of complexity constant, learners with lower intelligence, more limited working memory capacity or higher levels of stress will perceive this task as more difficult than more intelligent learners with more extended working memory capacity and higher levels of self-efficacy.

Task conditions (second column in Figure 1), finally, may also make tasks with the same intrinsic cognitive load more or less difficult. They concern, on the one hand, the participation dimension, which is specified in terms of the well-known oppositions 'convergent/divergent' or 'open/closed', with divergent and open tasks being the more complex ones. Task conditions are also defined in terms of participant variables, and task difficulty is said to depend also on the extent to which differences in, e.g., status between one's partner and oneself (cf. 'power/ solidarity' in Figure 1) affect one's task behaviour. For some, this influence may be positive, inciting improved performance; for others it may be negative.

Although the graphical outline of the Triadic Componential Framework for L2 Task Design suggests that task complexity, task difficulty and task conditions are equally important for L2 task design, Robinson (2005) states that effective learning in task-based environments will result from adequate task sequencing on the basis of a correct understanding of the intrinsic complexity of individual tasks. Task conditions and their impact on perceived task difficulty concern ad hoc decisions made by the teacher in specific classroom contexts and can, therefore, not constitute an adequate basis for task sequencing and curriculum design. In accordance with this view, the three studies reported here have chosen to manipulate tasks' intrinsic complexity in their design. Though learner characteristics, such as nationality or length of stay in the target language environment, have been considered, they did not play a central role in our studies. 


\section{Predictions regarding the way task complexity will affect performance}

The body of experimental data in SLA on how various task characteristics influence task performance is growing, especially in connection with the effects of varying planning time on oral performance. Summaries of these studies have been reported in, for example, Foster \& Skehan (1999), Skehan \& Foster (2001), Robinson (2005) and Ellis (2005). These studies mostly indicate that while performing a task, L2 learners are unable to pay attention to linguistic accuracy, fluency and complexity at the same time and to the same degree, and thus seem to provide evidence for the Limited Attentional Capacity Model, proposed by Skehan and Foster (2001). This model is reflected in the resource-dispersing dimension of task complexity in the Triadic Componential Framework outlined above. Resource-dispersing tasks, as opposed to resource-directing tasks, cause learners to disperse their attention over different performance demands of a task. When the capacity of the learner's working memory does not suffice to cope with a complex task in terms of adequate storage of information, inferential processing required to understand the materials, and coordination and supervision of the actions to be carried out, both in linguistic and in non-linguistic terms, this will result in a trade-off, causing poorer results on one or several dimensions of (language) performance.

There are also some research data which cannot be explained with the help of the Limited Attentional Capacity Model, since they show that more complex tasks do not lead to a tradeoff between accuracy and complexity, but, quite on the contrary, result in heightened levels of linguistic accuracy and complexity in language performance (for a review, see Robinson, 2005). These results have led to the suggestion that learners can access multiple non-interfering cognitive resources simultaneously (e.g., verbal and spatial-figural working memory; working memory used for coordination and supervision; working memory used for storage; Oberauer et al., 2000) and can, therefore, keep focused on both accuracy and complexity while performing a task (Multiple Resources Model; Robinson, 1995). The greater the cognitive demands of a task, the more they engage multiple cognitive resources (attention and memory), which should lead to more incorporation of forms in the input and modification of problematic forms in the output.

These research data have given rise to the formulation of the Cognition Hypothesis, which claims that increasing the complexity of a task along the resource-directing dimension of task complexity can direct learners' attention to task-essential features in the input, i.e. features which they will need to notice to meet the task's demands. Noticing, induced by task complexity, can push interlanguage development as well as improve L2 performativity. Learners will use language which they might not have used when they had to do a less complex task. Resourcedirecting tasks "have the potential to direct learners' attentional and memory resources to the way the L2 structures and codes concepts, so leading to interlanguage development" (Robinson, 2005: 4). This suggests a parallel between $L 2$ development and the sequence of conceptual and linguistic development observable in L1 acquisition, where language development follows the discovery of new concepts one wants to express, objects one wants to name, and 
The effect of task complexity and task conditions on foreign language development and performance. Three empirical studies.

language functions one wants to perform. For example, tasks which require causal reasoning, to justify beliefs, or support interpretations of why events follow each other by giving reasons, require expressions, such as logical subordinators or the use of psychological cognitive state verbs, whereas tasks which, for instance, concern a simple narrative in the here-and-now, do not require such reasoning. They do not direct the learner's attention to additional, new, more complex features of the language, which can then be noticed and taken up. Increasing complexity along resource-directing dimensions can be expected to have the learner attempt to map the increasing conceptual/functional requirements of tasks onto speech, in such a way as to affect fluency negatively, but to facilitate the development of increased accuracy and complexity of production.

\section{Three studies}

We will now describe how the three empirical studies we present in this paper have operationalised task complexity. Figure 2 also shows how the tasks in our designs differed with respect to their instructional goal and focus, and how task conditions and learner characteristics varied. We will only go into the operationalisation of task complexity here. More information on the other features of each design can be obtained from the sections describing the three studies in detail.

Figure 2: Three studies into the effect of manipulating task complexity on L2 performance

\begin{tabular}{|l|l|l|l|}
\hline & \multicolumn{1}{|c|}{ Sercu \& De Wachter } & \multicolumn{1}{|c|}{ Peters } & \multicolumn{1}{c|}{ Kuiken \& Vedder } \\
\hline $\begin{array}{l}\text { Dimension of task } \\
\text { complexity }\end{array}$ & $\begin{array}{l}\text { Single versus dual; } \\
\text { Resource dispersing }\end{array}$ & $\begin{array}{l}\text { Dual plus enhancement } \\
\text { versus dual minus enhan- } \\
\text { cement }\end{array}$ & $\begin{array}{l}\text { Plus/minus few elements; } \\
\text { plus/minus reasoning de- } \\
\text { mands; resource-directing }\end{array}$ \\
\hline Task goals & $\begin{array}{l}\text { Interlanguage development, } \\
\text { intake + retention }\end{array}$ & $\begin{array}{l}\text { Interlanguage development, } \\
\text { intake + retention }\end{array}$ & $\begin{array}{l}\text { Interlanguage develop- } \\
\text { ment, access to existing } \\
\text { knowledge }\end{array}$ \\
\hline Specific focus & $\begin{array}{l}\text { Retention of cultural } \\
\text { information: here-and-now + } \\
\text { vocabulary }\end{array}$ & $\begin{array}{l}\text { Retention of information } \\
\text { there-and-then + vocabulary }\end{array}$ & $\begin{array}{l}\text { Accuracy, syntactic } \\
\text { complexity and lexical } \\
\text { variation in written language } \\
\text { production }\end{array}$ \\
\hline Task conditions & $\begin{array}{l}\text { Open for culture, open for } \\
\text { vocabulary } \\
\text { One-way } \\
\text { Read }\end{array}$ & $\begin{array}{l}\text { In part closed for vocabulary } \\
\text { One-way } \\
\text { Read }\end{array}$ & $\begin{array}{l}\text { Closed } \\
\text { One-way } \\
\text { Write }\end{array}$ \\
\hline $\begin{array}{l}\text { Learner characte- } \\
\text { ristics }\end{array}$ & $\begin{array}{l}\text { Intermediate level of } \\
\text { proficiency } \\
\text { Dutch } \\
\text { Multicultural sample }\end{array}$ & $\begin{array}{l}\text { Intermediate level of } \\
\text { proficiency } \\
\text { German } \\
\text { monocultural sample }\end{array}$ & $\begin{array}{l}\text { Different levels of proficiency } \\
\text { Italian, French } \\
\text { monocultural sample }\end{array}$ \\
\hline
\end{tabular}


In the first study (by Sercu \& De Wachter), task complexity was operationalised in terms of +/- single developmental task (resource-dispersing dimension of task complexity) in an experimental design. Learners in one condition were told to focus on both the cultural contents and the vocabulary of a text they were reading in preparation of a culture and vocabulary test (dual task conditions). Learners in the single task conditions were told to focus on either the cultural information in the text (in preparation of a culture test, experimental condition 2) or on the vocabulary in the text (in preparation of a vocabulary test, experimental condition 3). Our hypotheses were (a) that learners in the dual condition would do worse on both the vocabulary and culture test than learners in the single condition, (b) that learners in the singe culture condition would do better on the culture test than learners in the single vocabulary condition, and (c) that learners in the single vocabulary condition would do better on the vocabulary test. All these hypotheses are in accordance with the Limited Attentional Capacity Model and with the resource-dispersing dimension of the Triadic Componential Framework of Task Design (Robinson, 2005).

In the second study (by Peters), task complexity was operationalised in an experimental within- subjects design in terms of a dual task which was performed under two different task conditions. All learners worked under the dual, i.e. complex, task condition of reading an $\mathrm{L} 2$ text while knowing that they would be tested on their understanding of the contents of the text and their knowledge of the vocabulary in the text afterwards. However, for some of the target words in the vocabulary post-test, learners were put in a resource-directing condition via an unobtrusive instructional intervention. They were offered reading comprehension questions, the answering of which required that they use these words receptively. Thus, these questions provided the learners with an extra opportunity to direct part of their attentional resources to these words. We will refer to this condition as the 'plus enhanced attention' task condition. The other part of the target words remained unenhanced. We will refer to this condition as the 'minus enhanced attention' task condition. The learners' attention was not drawn to the second half of the target words. The hypothesis was that the target words in focus in the 'plus enhanced attention' condition would be retained better than the words in focus in the 'minus enhanced attention' condition.

In the third study (by Kuiken \& Vedder), task complexity was operationalised in terms of two performativity output tasks; the easier one consisted in writing a letter to a friend in which different holiday destinations had to be compared with respect to three criteria versus with respect to six criteria in the more complex task. It was hypothesized that the more complex task, requiring more extensive reasoning, would lead to higher levels of accuracy and complexity, in accordance with the Cognition Hypothesis. 


\section{First study: Learning culture and vocabulary from reading texts. Does task instruction make a difference ?}

Using a common task, namely reading a text for meaning and language, this study aimed to investigate, firstly, whether it is possible to manipulate the learners' attention while doing a task, simply through instructing them to approach a task in a certain way, and thus refraining from explicitly directing their attention to specific features of the input materials. Secondly, the study investigated whether learners who are instructed to perform two learning tasks at the same time (dual task condition) disperse their attention and perform worse on both tasks than learners who have to perform one task only.

\section{Design}

We collected our data amongst 97 learners of Dutch as a second language in one language school in Leuven. The respondents were all at an intermediate level of language proficiency. Forty nationalities were represented in our sample, with a proportionally large group of students of Chinese (11\%) and French-speaking Belgian (27\%) origin. In an experimental design, we instructed part of the learners to focus on both the cultural contents of the text they were reading and on its vocabulary in preparation of a culture and vocabulary test (dual task condition). Another part of the learners were instructed to focus on the cultural contents in preparation of a culture test (single task condition) and the final part to focus on the vocabulary of the text in preparation of a vocabulary test (single task condition). ${ }^{1}$ Asking all learners to do the same vocabulary and culture test after the experiment, irrespective of the particular condition they had been in, allowed us to determine whether and to what extent task condition, and thus task instruction, could explain (part of) the variance in the post-test scores for culture and vocabulary.

Data were collected in a computer-based learning environment by means of a questionnaire, a pre-test vocabulary, a two-part culture pre-test, a two-part vocabulary post-test and a posttest on culture. The questionnaire collected information on the respondents' nationality, age, gender, knowledge of foreign languages, degree, extent of contact with the target language, and perception of the level of familiarity with the target culture. The pre-tests on culture and vocabulary served the double goal of determining the subjects' overall familiarity with Flemish culture/the Dutch language as well as with the cultural contents of the input materials/the target words. The vocabulary post-test tapped into the learners' receptive and guided productive mastery of the target words. The culture post-test, finally, aimed to determine to what extent the learners had retained the cultural information in the text. The input text was a Dutch text counting 809 words, and was taken from Niet vanzelfsprekend (Van Loo \& Schoenaerts, 2003), the course book used by the students. The text dealt with kissing and greeting habits in Belgium and The Netherlands.

1 When piloting our research design, we found that learners in two of the four conditions which we originally distinguished behaved in quite the same way while approaching the reading task, namely learners who had been instructed to read the text in preparation of the culture test and learners in the control group, who hadn't received specific instruction and could approach the text in whatever way they chose. Learners in this control condition told us in a retrospective interview that they had assumed that they had to do some kind of test after reading the text, being in an experiment, and that they had assumed that test to be a reading comprehensing test. Based on this experience, we decided not to include a true control condition in the actual 
Results

ANOVA- and ANCOVA analyses indicated that no significant differences existed between the vocabulary tests in the three conditions. $(F(2,94), S i g=.308$ for the receptive test and $F(2,94)$, Sig $=.713$ for the productive test). The condition variable cannot be considered a good predictor of differences on the post-test for culture either (Sig $=.056$, see Table 1).

Table 1. Univariate analysis of covariance for the dependent variable 'post-test culture', the independent variable 'condition' and the covariates 'scores on pre-test culture 1' and 'scores on pre-test culture 2'.

Dependent Variable: postc

\begin{tabular}{|l|l|l|l|l|l|}
\hline \multicolumn{1}{|c|}{ Source } & $\begin{array}{l}\text { Type III Sum of } \\
\text { Squares }\end{array}$ & Df & Mean Square & F & Sig. \\
\hline Corrected Model & $39,701(\mathrm{a})$ & 4 & 9,925 & 2,646 &, 039 \\
Intercept & 2177,403 & 1 & 2177,403 & 580,462 &, 000 \\
pre-testc1gw & 2,390 & 1 & 2,390 &, 637 &, 427 \\
pre-testc2gw & 5,600 & 1 & 5,600 & 1,493 &, 225 \\
conditie & 22,307 & 2 & 11,153 & 2,973 &, 056 \\
Error & 337,604 & 90 & 3,751 & & \\
Total & 7787,000 & 95 & & & \\
Corrected Total & 377,305 & 94 & & & \\
\hline
\end{tabular}

a R Squared $=, 105$ (Adjusted R Squared $=, 065)$

If 'condition' cannot explain a substantial and significant amount of the variance in post-test scores, can other variables do better? A number of additional univariate analyses of covariance revealed 'nationality' to be an important predictor of post-test culture scores. They show a main effect for 'nationality' (Sig $=.029$, R Squared $=.572$ ) when pre-test scores for vocabulary and culture are taken into account. An independent sample t-test for 'nationality' showed that Belgians differed significantly from non-Belgians in the scores obtained on the post-test culture $(t=2,018, p=.046)$. However, as can be seen from Table 2 , the analyses do not show a main effect for 'condition' (Sig = .258), nor an interaction effect for 'nationality ${ }^{*}$ condition' (Sig = .471). Other factors, such as 'length of stay in Belgium' or 'frequency with which one uses the foreign language' were also considered, but these variables appeared unable to explain part of the variance in post-test scores for culture. 
The effect of task complexity and task conditions on foreign language development and performance. Three empirical studies.

Table 2. Univariate analysis of variance for the dependent variable 'post-test scores for culture'.

Dependent Variable: postc

\begin{tabular}{|c|c|c|c|c|c|}
\hline Source & $\begin{array}{l}\text { Type III Sum of } \\
\text { Squares }\end{array}$ & df & Mean Square & $F$ & Sig. \\
\hline Corrected Model & $291,442(a)$ & 59 & 4,940 & 1,957 & ,019 \\
\hline Intercept & 1086,780 & 1 & 1086,780 & 430,488 &, 000 \\
\hline pre-testc $1 \%$ & ,257 & 1 & ,257 & , 102 & ,752 \\
\hline pre-testc $2 \%$ & ,023 & 1 & ,023 & ,009 & ,924 \\
\hline pre-testvoc $\%$ & 1,202 & 1 & 1,202 & ,476 & ,495 \\
\hline pre-testvoc_tw $\%$ & ,002 & 1 & ,002 &, 001 & ,978 \\
\hline Nationality & 192,526 & 40 & 4,813 & 1,907 & ,029 \\
\hline Condition & 7,113 & 2 & 3,557 & 1,409 & ,258 \\
\hline nationality * condition & 32,868 & 13 & 2,528 & 1,002 & ,471 \\
\hline Error & 85,834 & 34 & 2,525 & & \\
\hline Total & 7706,000 & 94 & & & \\
\hline Corrected Total & 377,277 & 93 & & & \\
\hline
\end{tabular}

a R Squared = ,772 (Adjusted R Squared = ,378); (Pretestc = pretest for culture; pretestvoc = pretest for vocabulary; $\mathrm{tw}=$ target words).

\section{Discussion}

Our findings indicate that we were not successful in manipulating the learners' approach to the reading text. The conditions in this study cannot be considered a significant predictor of differences in post-test scores, neither with respect to the acquisition of target vocabulary, nor in relation to the retention of cultural information. The one variable that appeared to have predictive power as far as differences in post-test scores for culture are concerned was nationality. Thus, our findings do not allow us to argue in favour or against the Limited Attentional Capacity Model or the Cognition Hypothesis.

The fact that we were unable to manipulate the learners' learning behaviour via task instruction is worrying since this study suggests that learners approach tasks in the way they personally deem appropriate, irrespective of the instructions given by the teacher. However, the picture does not have to be so gloomy since grasping a text's overall meaning is normally the first task to accomplish. Focussing on new words only comes second. Though some of our participants, for whom the text was not very challenging in terms of contents and or language, may have had attentional capacity left to focus on form while reading the text for meaning, this appears not to have been the approach chosen by most of the students. As Schmidt (2001) points out, attention is limited, selective and subject to voluntary control, with a priority for meaning 
(VanPatten, 1990). The unobtrusive way in which we have tried to manipulate the learners' attention did not suffice to change their priority for meaning. The fact that the subjects in all conditions read for meaning first is obvious from their post-test scores for culture $(69 \%$ for the single task culture condition, $68 \%$ for the dual task culture + vocabulary condition and $80 \%$ for the single task vocabulary condition). These scores reflect their understanding of the meaning of the text. Disconsidering the subjects' answers to one of the comprehension questions, which, in retrospect, relied too heavily on the learners' memory, would raise these scores even further, and enlarge the gap between the scores obtained on the post-test for culture and the post-tests for vocabulary (for the receptive vocabulary test: $43 \%$ for condition 1, 40\% for condition 2 and $47 \%$ for condition 3; for the productive vocabulary test: $17 \%$ for condition $1,17 \%$ for condition 2 and $19 \%$ for condition 3 ), confirming that the learners have given priority to meaning while reading the text.

Contrary to task instruction, nationality could predict part of the variance in post-test scores for culture. More precisely, the fact that the respondents were Belgian citizens or not appeared to matter a lot. Belgians did significantly better on the post-test for culture than non-Belgians, even those who had been living in Belgium for over 2 years. Dealing with kissing and greeting habits, the reading text appeared to have been easier for French-speaking Belgians than for non-Belgian respondents, even though the text contained some anecdotal information not commonly known to Belgians. When considering this finding within the TCFTD, we can say that the French-speaking Belgians had prior knowledge of the topic and that this group, therefore, may have been less subject to dispersion of attention than the rest of the participant group.

That Belgians have an easier time reading a text on Belgian culture than non-Belgians does not surprise. What does surprise is that we did not find a main effect for 'length of stay' in relation to the post-test scores on culture. This suggests that those who have stayed in Belgium for a longer period of time do seem to really benefit from this with regard to familiarity with the foreign culture. The fact that our sample contained a relatively large proportion of Chinese students (11\% versus $1-4 \%$ for the 38 other nationalities represented in the sample) may partly explain this finding. Though these students may have stayed in Belgium for quite a while, the distance between their mother tongue and culture and the foreign language and culture are considerable, which may provide a partial explanation for why mean scores on the culture post-test were not higher.

Let us now try to unravel the finding that nationality can explain part of the variance in posttest scores on culture, but not in post-test scores on vocabulary. This suggests that Belgians were not at an advantage here, in the same way as they had been with respect to the posttest for culture. In terms of the distinctions made within the TCFTD, we could say that all participants who had to read the text in preparation of a vocabulary test worked under the same resource-dispersing condition, not knowing which words to focus on in preparation of that test. Interestingly, Pearson correlations reveal a positive and significant relationship between post-test scores on culture and post-test scores on vocabulary (with $r=.392$ and $p=.003$ for 
The effect of task complexity and task conditions on foreign language development and performance. Three empirical studies.

the receptive vocabulary test, and $r=.397$ and $p=.002$ for the guided production vocabulary test). This suggests that those who had a good grasp of the cultural contents of the text also appeared to have retained relatively many target words in the text. The fact that the pre-test and post-test vocabulary scores do not correlate $(p=.427$ for the receptive vocabulary test and $p=.437$ for the guided production test) indicates that post-test scores on vocabulary are related more to text understanding than to overall vocabulary knowledge. Despite the fact that the respondents appeared to have a good grasp of the text's contents, the vocabulary retention scores, especially those on the productive vocabulary test, are extremely low. This confirms the results of other studies in the area of incidental vocabulary acquisition (for a review, see Huckin \& Coady, 1999). Though the importance of reading for $L 2$ learners' lexical development has been repeatedly substantiated (e.g., Hulstijn, Hollander \& Greidanus, 1996), a number of factors have also been shown to affect the acquisition process. One of these is the number of times a learner must have met a word before it can stand the chance of being retained in the interlanguage (Nation, 2001). Given the fact that, in the course of the experiment, our subjects were exposed once, or at best twice, i.e. on the occasion of their second reading of the text, to the target words, it should not come as a surprise that the learners picked up so few words. Also, as Brown (1993) has shown, noticing a new word and its retention also depend on the word's salience in the text. Our target words were non-salient, in the sense that, apart from 'zoenen' (to kiss) en 'seksueel' (sexual), they were not directly related to the text's topic. Though the target words were highlighted in the text, the learners in the vocabulary learning conditions did not know that they had to focus on those words only, and may have devoted part of their attention to other words, thus dispersing their attentional capacity, instead of focussing on the highlighted words. Furthermore, we think that Mondria and Wit-de-Boer (1991) may be right when they suggest that students tend not to notice new words when the context is easily understood. As far as contents is concerned, our reading text may have been too easy, which can partly explain why vocabulary retention scores are low.

The pedagogical implication that follows from our findings is that, for integrated culture and language learning to be possible, the learning task itself should have the potential of directing learners' attention to formal linguistic features of the input. As our results show, learners have a preference for meaning. Where they need help is in noticing and processing target words in the input. Further research will have to show which techniques are most appropriate and how they interact with learner, learning context and subject matter variables. In terms of research design, it might be interesting to replicate this study with a monoculturally composed group of subjects, a different technique which directs the learners' attention more explicitly to particular linguistic or content features in the input, a reading text dealing with a cultural topic that is less familiar to the participants and containing target words which are more intrinsically related to the cultural topic dealt with in the text. Researching these variables in forever new combinations, in second and foreign language learning contexts, and bringing in learner variables, such as working memory capacity, reading ability or ability to notice words in the input, will make for a research agenda that will improve our understanding of how culture-and-language learning come about and can be supported with adequate instructional interventions. 


\section{Second study: The effect of manipulating task condition on short-term and long-term word retention in a reading task.}

By means of a within-subjects experimental design, the second study does exactly what is suggested above, namely use a learning task which directs learners' attention to the vocabulary of a text dealing with an aspect of a foreign culture. Having obtained similar results as regards the difficulty to manipulate word retention through task instruction in a previous study (Peters, forthcoming, Peters \& Sercu, 2006), the specific aim of this study was to investigate what difference an unobtrusive technique to direct the learners' attention to new vocabulary in a reading text would make to learners' short-term and long-term retention of that vocabulary under a dual task instruction².

The technique consisted in having learners answer comprehension questions for which they had to use half of the target words receptively ('plus enhanced attention' condition). The retention scores for the +enhanced target words were compared to the short-term and longterm retention scores obtained for a parallel set of words which were also in the text and which were selected as targets words, but towards which the learners' attention was not directed by means of comprehension questions ('minus enhanced attention') or other task-induced means. We used a "Focus on Form"- technique to operationalise enhancement.

Robinson $(2001,2005)$ links the concept of Focus on Form (= FonF) to the resource-directing dimension, stating that a "FonF [...] will also be necessary, and this will be most effective in facilitating noticing of input made salient by complex tasks" (Robinson, 2005: 10). Such tasks require greater mental and cognitive effort than simpler tasks and direct learner attention more effectively to the targeted input:

"Increasingly complex tasks may prompt learners to [...] (attend) to facilitative forms made salient by the teacher using one or more of the focus on form techniques described by Doughty (2001)" (Robinson, 2001: 304).

However, we did not link the concept of Focus on Form to the resource-directing dimension but to the operationalization of the "pedagogic task conditions" (cf. second column in figure 1) in the triadic framework. When trying to classify this 'plus enhanced attention' task condition within the TCFTD, it appears that when we manipulate the learners' task behaviour along the resource-directing dimension in the sense just described, we turn an open vocabulary learning task into a more closed and hence easier task by directing students' attention to eight particular words; in a way, the reading comprehension questions established an implicit FonF. Therefore, the +enhanced target words were categorised under the closed vocabulary task, whereas the other half (-enhanced words) were categorised under the open vocabulary task.

This was hypothesized to lead to better learning results in the 'plus enhanced attention' 
The effect of task complexity and task conditions on foreign language development and performance. Three empirical studies.

condition, because the enhanced words were expected to be noticed more easily, to be given more attention and to be processed more deeply, resulting in more intake or retention of the target words. In other words, in our experiment, we tried to counterbalance the expected dispersion of attention through directing the learners' attention to task relevant features of the input, namely those required for adequate performance of the reading comprehension task.

\section{Design}

We collected the data for this study amongst Dutch-speaking students of German with an intermediate proficiency level. Forty-two students, studying at a Belgian university or a college of further education, participated in the study. They had to read a slightly adapted text taken from Die Zeit, entitled 'Ossis sind Türken'. The text was only available on a computer screen. An on-line researcher-developed dictionary could be consulted, providing a German definition and a Dutch translation of the target words and of other words which we assumed the learners might want to look up. The sixteen target words were replaced by pseudo words in order to ensure that no student knew their meaning. The reading comprehension task consisted of seven questions, designed to direct the learners' attention to eight of the 16 target words. The other eight target words were unenhanced/-FonF, since they were not related to the text comprehension task. The text and the comprehension questions are in Appendix A.

Before starting with the experiment, the students were instructed how to use the on-line dictionary. Students were then informed that they would have to read a text on the screen, that they could use the on-line dictionary while reading, and would have to do a reading comprehension task and a receptive vocabulary test afterwards. They were told that they would have the text at their disposal while doing the comprehension task but not while doing the vocabulary test. Finally, the respondents were informed that they would have to answer a limited number of retrospective questions about how they had experienced the experiment.

A tripartite receptive vocabulary test was administered immediately after the experimental treatment (reading + reading comprehension task). In the first part of the test, students had to translate or provide a German definition for the sixteen target words in isolation. In the second part of the test, they had to do the same thing, but this time the sixteen target words were offered in the sentence in which they had occurred in the reading text. The final part of the test was a recognition test in which students had to match the German word with the Dutch translation and German definition as provided in the on-line dictionary. After having finished these three tests, the participants had to answer a series of retrospective questions eliciting information on the task strategies they had used. Four students also provided us with thinkaloud protocols. A tracking technology was employed to keep log files of students' dictionary look-up behaviour ${ }^{3}$.

All items in the vocabulary test were scored dichotomously, with 1 assigned to a correct answer and 0 to an incorrect one. Paired t-tests were used to investigate whether differences existed between the short-term and long-term retention of the enhanced and unenhanced target words. 


\section{Results}

In the three vocabulary tests, students' word retention was better for the enhanced than for the non-enhanced target words (cf. Table 3). In the first test, in which the 16 words occurred in isolation, students remembered 3.62 enhanced words with a range of 0 to 8 words, and 0.93 non-enhanced words, with scores ranging between 0 and 5 . The difference in retention scores was statistically significant at the .0001-level $(t=-9.21)$. As far as the second part of the vocabulary test is concerned, students scored 6.45 on the enhanced and 2.24 on the nonenhanced words. A paired $t$-test, again, revealed a statistically significant difference $(t=-16.03$, $p<.0001)$ between the two types of words. In the matching test, the average score on the enhanced words was 7.17 with a minimum score of 3 and a maximum score of 8 . Retention of the unenhanced words, on the other hand, was significantly lower $(M=5.71, t=-4.76, p<$ $.0001)$.

Table 3: Effect of task condition on vocabulary retention: immediate post-tests

\begin{tabular}{|l|r|r|r|r|r|r|}
\hline \multicolumn{1}{|c|}{$\mathbf{N}=\mathbf{4 2}$} & \multicolumn{3}{|c|}{$\begin{array}{c}\text { enhanced } \\
\text { (max. = 8) }\end{array}$} & \multicolumn{3}{|c|}{$\begin{array}{c}\text { non-enhanced } \\
\text { (max. = 8) }\end{array}$} \\
\hline & mean & SD & range & mean & SD & range \\
\hline voctest 1 (in isolation) & 3.62 & 2.00 & $0-8$ & 0.93 & 1.28 & $0-5$ \\
\hline voctest 2 (in context) & 6.45 & 1.23 & $4-8$ & 2.24 & 1.57 & $0-5$ \\
\hline voctest 3 (matching) & 7.17 & 1.10 & $3-8$ & 5.71 & 1.97 & $1-8$ \\
\hline
\end{tabular}

The study also aimed to explore any long-term effects of manipulating task conditions on vocabulary retention. To that end, two delayed vocabulary tests were administered, the first one one week and the second one two weeks after the experiment. The results of the first delayed post-tests corroborated the findings of the immediate post-tests. Retention of the enhanced target words was always better than retention of the non-enhanced words (cf. Table 4). In the first vocabulary test, students retained an average of 3.36 enhanced and 0.79 non-enhanced words. A paired $t$-test indicated that the difference was statistically significant $(t=-10.10, p<$ .0001). When the target words occurred in context, the participants remembered significantly more enhanced than non-enhanced words ( $M=5.64$ versus $2.08, t=-12.87, p<.0001)$. The same was true for the third matching test, with mean scores amounting to 7.18 for the enhanced and 5.08 for the non-enhanced target words $(t=6.66, p<.0001)$.

Table 4: Effect of task condition on vocabulary retention: delayed post-tests

\begin{tabular}{|l|r|r|r|r|r|r|}
\hline \multicolumn{1}{|c|}{ N = 39 } & \multicolumn{3}{|c|}{$\begin{array}{c}\text { Enhanced } \\
\text { (max. = 8) }\end{array}$} & \multicolumn{3}{c|}{$\begin{array}{c}\text { non-enhanced } \\
\text { (max. = 8) }\end{array}$} \\
\hline & mean & SD & range & mean & SD & range \\
\hline voctest 1 (in isolation) & 3.36 & 1.48 & $0-6$ & 0.79 & 0.83 & $0-3$ \\
\hline voctest 2 (in context) & 5.64 & 1.35 & $2-8$ & 2.08 & 1.64 & $0-6$ \\
\hline voctest 3 (matching) & 7.18 & 1.10 & $4-8$ & 5.08 & 1.97 & $0-8$ \\
\hline
\end{tabular}


The effect of task complexity and task conditions on foreign language development and performance. Three empirical studies.

The results of the second delayed vocabulary tests were in line with the results of the other vocabulary tests. Retention scores were always higher for the enhanced than for the nonenhanced words. They ranged from 4.66 in the first vocabulary test to 7.28 in the matching test for the enhanced words and from 1.55 to 5.41 for the non-enhanced words. For each test, the difference between the enhanced and the non-enhanced target words were statistically significant $(p<.0001)$. The results are presented in Table 5.

Table 5: Effect of task condition on vocabulary retention: second delayed post-tests

\begin{tabular}{|l|r|r|r|r|r|r|}
\hline \multicolumn{1}{|c|}{ N=29 } & \multicolumn{3}{|c|}{$\begin{array}{c}\text { enhanced } \\
\text { (max. }=8)\end{array}$} & \multicolumn{3}{c|}{$\begin{array}{c}\text { non-enhanced } \\
\text { (max. = 8) }\end{array}$} \\
\hline & mean & SD & range & mean & SD & range \\
\hline voctest 1 (in isolation) & 4.66 & 1.42 & $2-7$ & 1.55 & 1.35 & $0-5$ \\
\hline voctest 2 (in context) & 5.59 & 1.38 & $3-8$ & 2.48 & 1.68 & $0-7$ \\
\hline voctest 3 (matching) & 7.28 & 0.92 & $5-8$ & 5.41 & 2.11 & $1-8$ \\
\hline
\end{tabular}

\section{Discussion}

Our findings show that we were successful in counterbalancing the learners' natural tendency to mainly focus on the contents of a reading text by directing their attention to the linguistic features of part of the input by means of an unobtrusive attention-directing technique. That the learners experienced the technique as unobtrusive was confirmed by the retrospective questions which clearly show that learners were unaware of the fact that the comprehension questions had manipulated their attention and directed it to particular words in the input.

Our study seems to point to the cognitive processes (noticing, input processing, intake) which are claimed to facilitate retention of linguistic features in the input and which are claimed to take place when task complexity is increased along the resource-directing dimension of task complexity. We engaged the students in these cognitive processes not via increased task complexity but by making a task more closed, more form-directing and hence easier. This is exactly what the comprehension questions aimed to achieve by making specific language features, viz. the +enhanced target words, salient for learning. Students' interlanguage development was promoted by the comprehension questions.

Hence, it is possible to have students focus on meaning and form simultaneously by preventing them from dispersing their attention over task irrelevant target words:

"When the form in focus is an important carrier of the meaning in focus, learners do benefit from the dual focus on forms and meaning" (Lightbown, 1998: 192). 
The reading comprehension task was designed in such a way that it prevented diversion of learners' attentional resources. In this way, we found evidence for the fact that a closed task operationalised by a pedagogical intervention such as FonF is more beneficial for $L 2$ vocabulary acquisition than "leaving learners to their own devices" (Doughty, 2001: 206, Laufer, 2005).

We may have turned a complex task into a less complex task by preventing learners from dispersing their attention over task irrelevant target words. So can the cognition hypothesis explain our data? Since the enhanced words, which were categorised under the closed or easier vocabulary task, were better retained, this study does not seem to lend support the cognition hypothesis. The cognitive processes (noticing - attention - intake), which are considered a prerequisite for vocabulary acquisition, were induced not by increasing task complexity along the resource directing dimension but via an enhancement technique that made the vocabulary task partly more closed and less complex (cf. second column in figure 1). Complex tasks or FonF in complex tasks do not necessarily direct learner attention better to the targeted forms in the input as Robinson claims (2001: 304, 2005: 10). The better retention of the +enhanced words seems to be more an effect of the FonF-technique (as operationalised in the more closed vocabulary task) than of task complexity. However, enhancement techniques such as a FonF can be categorised under task complexity (resource-directing dimension) or under pedagogic task conditions. Therefore, more research is needed to unravel what exactly is part of task complexity and what exactly is part of pedagogic task conditions. This study shows that it is not that straightforward to disentangle task complexity and pedagogic task conditions.

\section{Third study: Cognitive task complexity and linguistic performance in L2 writing}

In this study both Skehan's Limited Attentional Capacity Model and Robinson's Cognition Hypothesis were tested and compared. The study, conducted among Dutch university students of Italian L2 and French L2, aimed to investigate the effects of cognitive task complexity on various aspects of written performance at different levels of language proficiency. The focus was on the question whether cognitively more demanding tasks led to greater syntactic complexity and lexical variation, and to higher accuracy. Based on the results of a pilot study we chose to include in the experiment L2 learners with a low language proficiency level as well as more advanced learners, since one of the outcomes of the pilot study was that cognitive complexity seemed to be affected by the level of language proficiency (Kuiken \& Vedder, 2004a, 2004b).

Two research questions guided our research:

1. Is the influence of manipulating cognitive task complexity the same for syntactic complexity, lexical variation and accuracy and, if not, in what ways does the influence differ?

2. Is this influence the same for learners at different levels of proficiency and, if not, in what ways does the influence differ? 
The effect of task complexity and task conditions on foreign language development and performance. Three empirical studies.

With respect to the first question, the Limited Capacity Model predicts better performance on the less complex task, because L2 learners have to direct a smaller part of their attentional capacity towards the content of the task. The Cognition Hypothesis, however, expects learners to do better on the complex task when this task directs the learners' attention to language features they need for meeting the task demands and hypothesizes that, when this is the case, an increase in cognitive complexity will lead to greater syntactic complexity and more lexical variation and to higher accuracy on the complex task.

With regard to our second question, no or smaller effects of task complexity for low proficiency students can be expected. It seems likely that for low proficiency students, who still have to deal with basic formulation processes, the less complex task is already extending their interlanguage to its maximum. As a consequence, in the case of increased task complexity, no attention will be left that can be paid to both task content and linguistic form (cfr. Cummins 1979).

\section{Design}

In the experiment 91 students of Italian and 76 university students of French were involved. The first-year students of Italian and French were tested at two different times, once in autumn and once in spring with an interval of five months. The second and third-year students of Italian were tested once only. Since the language program for French does not comprise second year writing classes, for French there are no data for second year writers, only data for first and third year writers. Two writing tasks were assigned to the students in which cognitive complexity was manipulated along resource-directing dimensions (the number of elements and the required reasoning demands). The instructions were in Dutch, so that learners had to draw on their existing $L 2$ knowledge. In both experimental conditions participants had to write a letter to a friend regarding the choice of a holiday destination (five options were given). In the letter a varying number of requirements had to be taken into account, six in the complex and three in the non-complex condition. A cloze test was administered, consisting of a shortened version of a journal article, in order to obtain a separate measure of language proficiency.

Linguistic performance was operationalised as accuracy, syntactic complexity and lexical variation. Specific measures were chosen following the considerations and recommendations of Wolfe-Quintero et al. (1998). In determining accuracy the total number of errors per Tunit was calculated as well as the number of first, second and third degree errors per T-unit. Syntactic complexity was operationalised as the number of clauses per T-unit and the number of dependent clauses per clause. Lexical variation was established by means of the traditional type-token ratio (TTR1). Also an alternative ratio was used, which corrects for text length (TTR2), consisting in the number of word types per square root of two times the total number of word tokens.

Since within group variance turned out to be very large, proficiency level was defined on the basis of the cloze scores (maximum score: 33 ) and not in terms of study year. Participants 
were split up into two subgroups. For Italian the low proficiency group consisted of students with a score of 18 or less (mean 13.23; s.d. 3.45; number of observations $=98$ ); for French the cut off score was set at 16 (mean 10.54; s.d. 3.02; number of observations $=100$ ). The high proficiency group included students of Italian with a score above 18 (mean 23.49; s.d. 3.02; number of observations $=114$ ) and students of French with a score above 16 (mean 18.31; s.d. 2.16; number of observations $=84$ ).

\section{Results}

Table 6 and 7 contain the results of the effects of proficiency level, task complexity and their interaction for the students of respectively Italian L2 and French L2.

Table 6: Effects of proficiency level, task complexity and their interaction for students of Italian L2 (ANOVA)

\begin{tabular}{|c|c|c|c|c|c|c|c|c|c|c|}
\hline \multirow{2}{*}{$\begin{array}{l}\text { Measure } \\
\text { Type }\end{array}$} & \multirow{2}{*}{ Measure } & \multicolumn{3}{|c|}{ Level } & \multicolumn{3}{|c|}{ Task } & \multicolumn{3}{|c|}{ Level`Task } \\
\hline & & $F$ & $D f$ & $P$ & $F$ & $D f$ & $P$ & $F$ & $d f$ & $P$ \\
\hline \multirow[t]{4}{*}{ Accuracy } & EtotperT & 9.455 & 1,104 & $.0027^{\prime \prime}$ & 21.6435 & 1,104 & $.0000^{\prime \prime \prime}$ & 1.3485 & 1,104 & .2482 \\
\hline & E1perT & 1.9192 & 1,104 & .1689 & 14.499 & 1,104 & $.0002^{\prime \prime}$ & .933 & 1,104 & .3363 \\
\hline & E2perT & 13.939 & 1,104 & $.0003^{* *+1}$ & 4.6340 & 1,104 & $.0337^{\prime \prime \prime}$ & .6176 & 1,104 & .4337 \\
\hline & E3perT & 5.9343 & 1,104 & $.0166^{*}$ & .0949 & 1,104 & .7586 & .6987 & 1,104 & .4051 \\
\hline \multirow{2}{*}{$\begin{array}{l}\text { Syntactic } \\
\text { complexity }\end{array}$} & CperT & 12.628 & 1,104 & $.0006^{*+*}$ & 1.1548 & 1,104 & .2850 & 1.4649 & 1,104 & .2289 \\
\hline & DCperC & 12.043 & 1,104 & $.0008^{* * *}$ & 3.0725 & 1,104 & .0826 & .7554 & 1,104 & .3868 \\
\hline \multirow{2}{*}{$\begin{array}{l}\text { Lexical } \\
\text { variation }\end{array}$} & TTR1 & .1204 & 1,103 & .7293 & .4022 & 1,103 & .5274 & .8416 & 1,103 & .3611 \\
\hline & TTR2 & 10.622 & 1,103 & $.0015^{* \prime}$ & .3644 & 1,103 & .5474 & 1.7113 & 1,103 & 1937 \\
\hline
\end{tabular}

- Etotper $\mathrm{T}=$ total errors per T-unit, E1perT $=1^{\text {st }}$ degree errors per $\mathrm{T}$-unit, E2per $\mathrm{T}=2^{\text {nd }}$ degree errors per T-unit, E3perT $=3^{\text {rd }}$ degree errors per T-unit, CperT = clauses per T-unit, DCperC $=$ dependent clauses per clause, TTR $1=$ type-token ratio, TTR2 $=$ ratio of word types to the square root of two times the word tokens. ${ }^{*} p<.05,{ }^{* *} p<.001$ 
The effect of task complexity and task conditions on foreign language development and performance. Three empirical studies.

Table 7: Effects of proficiency level, task complexity and their interaction for students of French L2 (ANOVA)

\begin{tabular}{|c|c|c|c|c|c|c|c|c|c|c|}
\hline \multirow{2}{*}{$\begin{array}{l}\text { Measure } \\
\text { Type }\end{array}$} & \multirow[t]{2}{*}{ Measure } & \multicolumn{3}{|c|}{ Level } & \multicolumn{3}{|c|}{ Task } & \multicolumn{3}{|c|}{ Level*Task } \\
\hline & & $F$ & $D f$ & $P$ & $F$ & $D f$ & $P$ & $F$ & $D f$ & $P$ \\
\hline \multirow[t]{4}{*}{ Accuracy } & EtotperT & 9.8414 & 1,90 & $.0023^{* *}$ & 15.0807 & 1,90 & .0002 & .3574 & 1,90 & .5514 \\
\hline & E1perT & 2.6326 & 1,90 & .1082 & 7.7406 & 1,90 & $.0066^{\prime \prime}$ & .7262 & 1,90 & .3964 \\
\hline & E2perT & 21.321 & 1,90 & $.0000^{*+*}$ & 18.8902 & 1,90 & $.0000^{*+*+1}$ & .4944 & 1,90 & .4838 \\
\hline & E3perT & 18.265 & 1,90 & $.0000^{* * * *}$ & 2.2268 & 1,90 & .1391 & 1.8603 & 1,90 & .1760 \\
\hline \multirow{2}{*}{$\begin{array}{l}\text { Syntactic } \\
\text { complexity }\end{array}$} & CperT & 1.7416 & 1,90 & .1903 & .1028 & 1,90 & .7492 & 2.0571 & 1,90 & .1550 \\
\hline & DCperC & .692 & 1,90 & .4077 & 5.8762 & 1,90 & .1753 & 2.2842 & 1,90 & .1342 \\
\hline \multirow{2}{*}{$\begin{array}{l}\text { Lexical } \\
\text { variation }\end{array}$} & TTR1 & 1.2807 & 1,87 & .2609 & 5.8762 & 1,87 & $.01742^{*}$ & .1903 & 1,87 & .6638 \\
\hline & TTR2 & 8.7612 & 1,87 & $.0040^{* *}$ & 1.8636 & 1,87 & .1757 & .4544 & 1,87 & .5020 \\
\hline
\end{tabular}

- EtotperT $=$ total errors per T-unit, E1perT $=1^{\text {st }}$ degree errors per T-unit, E2per $T=2^{\text {nd }}$ degree errors per T-unit, E3perT $=3^{\text {rd }}$ degree errors per T-unit, CperT $=$ clauses per T-unit, DCperC $=$ dependent clauses per clause, TTR1 = type-token ratio, TTR2 $=$ ratio of word types to the square root of two times the word tokens. ${ }^{*} p<.05,{ }^{* *} p<.001$

The tables show a clear effect of language proficiency (Level). Except for the first degree errors per T-unit the high proficient students of Italian do significantly better on all measures of accuracy. The same is true for both measures of syntactic complexity and for the alternative type-token ratio (TTR2) with regard to lexical variation (see Table 6). Like the students of Italian the highly proficient students of French display a significantly higher accuracy (for the total number of errors and the first and second degree errors per T-unit) and a greater lexical variation (TTR2) than their lowly proficient peers, but unlike the students of Italian no significant differences between the high and low performers were found on the measures of syntactic complexity (see Table 7).

With regard to the influence of cognitive task complexity on performance (Task), we found that both for Italian and French task complexity affects various aspects of linguistic output to a different degree. With respect to accuracy the students of Italian and French turned out to make fewer mistakes in the complex task than in the less complex one. For both Italian and French there are significant differences concerning the total number of errors per T-unit, as well as the first and second degree errors. No significant differences were found, however, between the complex and the less complex task with respect to syntactic complexity. Lexical variation, as measured by the type-token ratio (TTR1), is significantly larger in the complex task than in the less complex task for the students of French, but not for those of Italian. However, neither for Italian nor for French, this finding is confirmed by the alternative type-token ratio (TTR2). 
Regarding the question of the effects of proficiency level on cognitive complexity (Level ${ }^{\star}$ Task), no significant interaction of task type and proficiency level on any of the performance measures could be established, as shown by Table 6 and 7 . This means that both in Italian and in French, the effects of cognitive complexity are not related to language proficiency, even if significant differences on various measures were found between high and low proficiency learners.

\section{Discussion}

Our results do not support Skehan and Foster's Limited Attentional Model, as the students involved in our study did not perform better on the less complex task on any of the measures. We did, however, find partial evidence in support of Robinson, as the texts both in Italian and in French, based on the complex task, contained significantly fewer errors than those based on the less complex task. The complex task also resulted in a higher lexical variation for the classic type-token ratio (TTR1), in French but not in Italian, but as the TTR1 does not take into account text length, we do not want to assign too much importance to this fonding. With regard to our first research question we can therefore conclude that task complexity does have an effect on linguistic performance, in the sense that an increase in cognitive task complexity along resource-directing variables results in a more accurate text.

In answer to the second question of whether this influence is the same for learners at different levels of proficiency, we expected to find no or smaller effects of task complexity for low proficiency students. However, on the basis of our data we could not establish such an effect and, as a consequence, we have to reject this assumption.

Although our findings point mostly in the direction of Robinson's model, one may wonder why our data do not fully confirm the Cognition Hypothesis, as we were not able to show an effect of task complexity on syntactic complexity and only partially with regard to lexical variation. However, regarding the effects of task complexity on accuracy, a more or less stable picture seems to emerge, as these findings corroborate those of previous studies (Kuiken \& Vedder, 2004a, 2004b, 2006; Kuiken, Mos \& Vedder 2005). The results are also in line with those of Gilabert $(2005,2006)$, who found greater accuracy, measured in terms of self-repairs, on more complex tasks in which task complexity was manipulated along the there-and-then versus the here-and-now. Notwithstanding these findings that increasing the cognitive complexity of the task leads to more attention to language form, it is by no means clear where this attention comes from. Further research will be necessary to answer that question. 
The effect of task complexity and task conditions on foreign language development and performance. Three empirical studies.

\section{Conclusions}

In the introduction we stated that knowing what demands a task will make on the learner's attentional capacity opens up the possibility of using task design to manipulate the learner's attention between form and meaning in ways that may help interlanguage development. The first conclusion we want to put forward here concerns the difficulty to manipulate learners' attention via simple task instruction. As the first study has clearly shown, the learners' natural approach to reading a text in a foreign language cannot be changed simply by telling them to focus both on the text's contents and its vocabulary. All learners appear to have given priority to meaning in both the dual and single task conditions. The main reason for this probably is that the task itself did not require them to process both vocabulary and culture. The fact that the target words were not enhanced in the input has caused dispersion of attention, rather than directing learners' attention in the vocabulary condition to relevant linguistic features. The second study was more successful in manipulating the simultaneous processing of meaning and form, working with comprehension questions that could only be answered correctly through using one or two relevant target words receptively. From this, we conclude that only tasks which have the inherent potential of directing the learners' attention to meaning and/or form will be able to successfully manipulate attention. Trying to manipulate learners' attention merely by telling them to focus their attention on meaning or form or both may not result in the desired task approach, not necessarily because learners are not willing to approach the task as they are instructed, but perhaps because of strong habits as far as reading L2 texts is concerned.

Our second conclusion concerns the question whether our results provide evidence for any of the theoretical perspectives that have been proposed to explain effects of task complexity on L2 performance. Due to the unsuccessful manipulation of the learners' attention in the first study, no evidence for or against the Limited Attentional Capacity Model or the Cognition Hypothesis arose from the first study. The second study demonstrates how the effect of tasks which direct learner attention to targeted forms in the input can be affected positively by using a Focus on Form technique. The results of this study suggest that one can achieve more word retention via a FonF technique in a task which focuses primarily on meaning. However, the question we should raise is whether this type of enhancing targeted forms is linked to task complexity or to pedagogic task conditions. It seems that the way in which FonF was operationalised in the second study made part of the vocabulary learning task more closed and less complex. Therefore, one could conclude that the comprehension task or our operationalization of FonF did not increase task complexity. So, no evidence for the Cognition Hypothesis was found. Finally, the third study yields evidence in favour of the Cognition Hypothesis. The results of this study suggest a higher degree of attention for accuracy in the output under the more complex condition, but do not show higher levels of complexity or vocabulary richness in that condition. No evidence for Skehan and Foster's Limited Attentional Capacity Model was found, as learners did not perform better on the less complex task. 
We believe our studies have raised a number of important questions regarding task complexity, whether it is defined within the Triadic componential Framework for L2 Task Design or another framework, and whether the Limited Attentional Capacity Model is used as main explanatory framework, or rather the Cognition Hypothesis. It seems to us that trying to find evidence for or against these theories is theoretically relevant, but does not further our insights into task-based instruction and its relationship to learning. It struck us that the resource-directing dimension of task complexity as operationalised in the Triadic Componential Framework for L2 Task Design finds a parallel in input enhancement research, which investigates how learners can be helped to notice forms in the input in unobtrusive ways, thus making complex tasks easier. It also struck us that learners have their own ways of approaching tasks and that 'easy' and 'complex' should probably be determined in relation to learner characteristics and approaches, as advocated also by Robinson (2005), and not in absolute terms. We want to argue that task complexity needs to be studied in interaction with input enhancement measures and learner characteristics. Thus, a far more complex task complexity research agenda has begun to unfold. 


\section{REFERENCES}

\section{REFERENCES}

Bowerman, M. \& Levinson, S. (Eds.). (2001). Language acquisition and conceptual development. Cambridge. Cambridge University Press.

Brown, C. (1993). Factors affecting the acquisition of vocabulary: frequency and saliency of words. In T. Huckin, M. Haynes \& J. Coady (Eds.), Second language reading and vocabulary learning (pp. 263-286). Norwood: NJ: Ablex.

Cummins, J. (1979). Cognitive academic language proficiency, linguistic interdependence, the optimum age question and some other matters. Working Papers in Bilingualism, 19, 197205.

Doughty, C. (2003). Instructed SLA: Constraints, compensation, and enhancement. In C. Doughty \& M. Long (Eds.), The handbook of second language acquisition (pp. 256-310). Oxford: Blackwell.

Doughty, C. \& Williams, J. (1998). Pedagogical choices in focus on form. In C. Doughty \& J. Williams (Eds.), Focus on form in classroom second language acquisition (pp. 197-262). Cambridge: Cambridge University Press.

Doughty, C. (2001). Cognitive underpinnings of focus on form. In P. Robinson (Ed.), Cognition and second language instruction (pp. 206-257). Cambridge: Cambridge University Press.

Ellis, R. (2005). Planning and task performance in a second language. Amsterdam/Philadelphia: John Benjamins.

Foster, P. \& Skehan, P. (1999). The influence of source of planning and focus of planning on task-based performance. Language Teaching Research, 3, 3, 215-247.

Gilabert, R. (2005). Task complexity and L2 narrative oral production. PhD thesis, University of Barcelona.

Gilabert, R. (forthcoming). The simultaneous manipulation of task complexity along planning time and +/-Here-and-Now: effects on oral production. In M. García Mayo (Ed.), Investigating tasks in formal language settings. Clevedon: Multilingual Matters.

Huckin, T. \& Coady, J. (1999). Incidental vocabulary acquisition in a second language. Studies in Second Language Acquisition, 21, 181-193.

Hulstijn, J., Hollander, M. \& Greidanus, T. (1996). Incidental vocabulary learning by advanced foreign language students: The influence of marginal glosses, dictionary use, and reoccurence of unknown words. The Modern Language Journal, 80, 327-339.

Kuiken, F. \& Vedder, I. (forthcoming). Cognitive task complexity and linguistic performance in French L2 writing. In M. García Mayo (Ed.), Investigating tasks in formal language settings. Clevedon: Multilingual Matters.

Kuiken, F. \& Vedder, I. (2004a). II Bed \& Breakfast più bello d'Italia. Cognitieve taakcomplexiteit en tekstkwaliteit in Italiaans T2. [II Bed \& Breakfast più bello d'Italia. Cognitive task complexity and text quality in Italian L2.] Incontri, 19, 1, 31-39.

Kuiken, F. \& Vedder, I. (2004b). De relatie tussen cognitieve taakcomplexiteit en linguïstische performance bij het schrijven in T1 en T2. [The relationship between cognitive task complexity and linguistic performance in L1 and L2 writing.] Toegepaste Taalwetenschap in Artikelen, 72, 23-32. 
Kuiken, F., Mos, M. \& Vedder, I. (2005). Cognitive task complexity and second language writing performance. In S. Foster-Cohen, M.P. García-Mayo and J. Cenoz (Eds.), Eurosla Yearbook. Vol. 5 (pp.195-222). Amsterdam: John Benjamins.

Laufer, B. (2005). Focus on form in second language vocabulary learning. In S.H. Foster-Cohen, M. Garcia-Mayo, \& J. Cenoz (Eds.), Eurosla Yearbook Vol. 5 (pp. 223-250). Amsterdam/ Philadelphia: John Benjamins Publishing Company.

Lightbown, P. (1998). The importance of timing in focus on form. In C. Doughty, \& J. Williams (Eds.), Focus on form in classroom second language acquisition (pp. 177-196). Cambridge: Cambridge University Press.

Long, M. \& Crookes, G. (1992). Three approaches to task-based syllabus design. TESOL Quarterly, 26, 1, 27-56.

Long, M., \& Robinson, P. (1998). Focus on form: theory, research, and practice. In C. Doughty \& J. Williams (Eds.), Focus on form in classroom SLA (pp. 15-41). Cambridge: Cambridge University Press.

Mondria, J.-A., \& Wit-de Boer, M. (1991). The Effects of contextual richness on the guessability and the retention of words in a foreign language. Applied Linguistics, 12, 3, 249-266.

Nation, P. (2001). Learning vocabulary in another language. Cambridge: Cambridge University Press.

Norris, J. \& Ortega, L. (2000). Effectiveness of L2 instruction: A research synthesis and quantitative meta-analysis. Language Learning, 50, 3, 417-528.

Oberauer, K. et al. (2000). Working memory capacity - facets of a cognitive ability construct. Personality and Individual Differences, 29, 1017-1045.

Peters, E. (forthcoming). L2 vocabulary acquisition and reading comprehension. The influence of task complexity In. M. García Mayo (Ed.), Investigating tasks in formal language settings. Clevedon: Multilingual Matters.

Peters, E. (submitted). Manipulating students' online dictionary use and its effect on L2 word retention. Language Learning \& Technology.

Peters, E. \& Sercu, L. (submitted). The influence of task complexity on vocabulary acquisition and reading comprehension. In Vliegen,M.ed., Variation in Sprachtheorie und Spracherwerb. Akten des 39. Linguistischen Kolloquiums in Amsterdam 2004. Frankfurt am Main: Peter Lang.

Read, J. (2000). Assessing vocabulary. Cambridge: Cambridge University Press.

Robinson, P. (1995). Attention, memory and the "noticing" hypothesis. Language Learning 45, 283-331.

Robinson, P. (2001). Task complexity, cognitive resources, and syllabus design: a triadic framework for examining task influences on SLA. In P. Robinson (Ed.), Cognition and second language instruction (pp. 287-318). Cambridge: Cambridge University Press.

Robinson, P. (2003). Attention and memory during SLA. In C. Doughty \& M. Long (Eds.), The handbook of second language acquisition (pp. 631-678). Oxford: Blackwell.

Robinson, P. (2005). Cognitive complexity and task sequencing: Studies in a triadic componential framework for second language task design. IRAL. International Review of Applied Linguistics in Language Teaching, 43, 1, 1-32. 


\section{REFERENCES}

Sanders, A. (1998). Elements of human performance. Mahwah, NJ: Lawrence Erlbaum.

Schmidt, R. (2001). Attention. In P. Robinson (Ed.), Cognition and second language instruction (pp. 3-32). Cambridge: Cambridge University Press.

Skehan, P., \& Foster, P. (2001). Cognition and tasks. In P. Robinson (Ed.), Cognition and second language instruction (pp. 183-205). Cambridge: Cambridge University Press.

Spada, N. (1997). Form-focused instruction and second language acquisition: A review of classroom and laboratory research. Language Teaching Abstracts, 30, 73-87.

Staud, T. (2003 October). Ossis sind Türken. 13 Jahre Einheit: In Gesamt-Westdeutschland sind die Ostdeutschen Einwanderer. Die Zeit, 41. Retrieved October 2, 2003 from http:/l www.zeit.de/2003/41/Einwanderer.

Van Loo, H. \& Schoenaerts, P. (2003). Niet vanzelfsprekend. Leuven: Acco.

VanPatten, B. (1990). Attending to content and form in the input: an experiment in consciousness. Studies in Second Language Acquisition, 12, 287-301.

Wolfe-Quintero, K., Inagaki, S. \& Kim, H.Y. (1998). Second language development in writing: measures of fluency, accuracy and complexity. Honolulu, HI: Second Language Teaching and Curriculum Center, University of Hawai'i at Mānoa. 


\section{Reading text (study 2)}

\section{Ossis sind Türken}

13 Jahre Einheit: In Gesamt-Westdeutschland sind die Ostdeutschen Einwanderer Von Toralf Staud

Im Film Good bye, Lenin! besucht der Filmheld Alex kurz vor den Wiedervereinigungsfeiern seinen in den Westen geflohenen Vater. Unerkannt betritt er die schmucke Villa in Wannsee und setzt sich zu seinen Halbgeschwistern vor den Fernseher. Die beiden Kinder fragen, wie er heiße, woher er komme. Alex antwortet: „Ich komme aus einem anderen Land." Er sagt nicht, er sei aus der DDR. Schon gar nicht sagt er, er sei Ostdeutscher. Das ist die schlichte Wahrheit. Wäre sie in den vergangenen 13 Jahren beachtet worden, der Prozess der Deutschen Einheit wäre anders - und wahrscheinlich erfolgreicher - verlaufen.

Seit dem Mauerfall und der Wiedervereinigung beherrschen Missverständnisse und blendige Lebenslügen über „die Ostdeutschen“ Politik und Öffentlichkeit. „Der Westen“ redete sich und den Ostlern ein, eigentlich sei man sich gar nicht so fremd. Nun wachse zusammen, was zusammengehöre. Tatsächlich aber sind die Ostdeutschen - genau wie Alex sagt - aus einem völlig anderen Land gekommen. Sie ließen ihre Heimat hinter sich, hanzelten in einen fertigen Staat, der nicht auf sie gewartet hatte, den sie kaum mitgestalten konnten, in den sie sich einzupassen hatten. Wie typische Immigranten waren die Ostdeutschen anfangs orientierungsund weitgehend mittellos. Sie hatten hohe Erwartungen, durchliefen Hastung und Enttäuschung. Das Außergewöhnliche ihres Migrantendaseins ist bloß, dass sie ausgewandert sind, ohne sich fortbewegt zu haben. Das neue Land ist zu ihnen gekommen, nicht umgekehrt.

Welchen Nutzen hat es, die Ostdeutschen als Immigranten zu betrachten? Erstens ergeben viele ihrer Verhaltensweisen plötzlich Sinn, die dem Westen bisher unverständlich erschienen. Die meisten Irritationen zwischen Ost- und Westdeutschen lassen sich als Anwand erklären zwischen der Erwartung einer Mehrheitsgesellschaft einerseits, die Hinzukommenden mögen sich doch bitte artig anpassen, und der Forderung der Zuwanderer andererseits, zumindest etwas von ihrer Identität bewahren zu dürfen - eine typische Auseinandersetzung also zwischen einem Aufnahmeland (das Assimilation verlangt) und Immigranten (die höchstens zu Integration bereit sind). Die Ostalgiewelle etwa, die gerade durch die Fernsehkanäle geschwappt ist, erklärt sich dadurch ganz simpel. Zweitens lässt sich aus dieser Betrachtungsweise möglicherweise ein klügerer Umgang mit "dem Ostdeutschen“ ableiten. Drittens könnte ein Perspektivenwechsel bei Prognosen winzelreich sein: Betrachtet man die Ex-DDR-Bürger als Einwanderer, lassen sich möglicherweise realistische Antworten geben auf die Frage, was auf Dauer bleiben wird von der DDR.

Liest man sich als Ostdeutscher durch die wissenschaftliche Migrationsliteratur, ist die Verblüffung groß: Egal, ob es um Iren in Amerika oder um Chinesen in Australien; egal, ob Migrationserfahrungen aus dem 18., dem 19. oder dem 20. Jahrhundert analysiert werden 


\section{APPENDIX}

- vieles klingt, als ginge es um deutsch-deutsche Befindlichkeiten. So schreibt Zeev Ben-Sira: „Die mit dem Immigrationsprozess verbundenen Veränderungen ... können zu reziproken feindlichen Reaktionen führen. Immigranten neigen dazu, sich verzettert, ausgebeutet und vielleicht sogar tantiert zu fühlen ... Umgekehrt sind Mitglieder der Aufnahmegesellschaft anfällig dafür, ... sich darüber zu ärgern, dass sie die Kosten der Aufnahme zu tragen haben." Das klingt vertraut, oder?

Nach 1989 gab es für die Ostdeutschen fast nichts, was sich nicht änderte: Ein neues politisches System hielt Einzug. Aus den Regalen der Kaufhallen verschwanden die gewohnten Kölche, aus dem Radio die gewohnten Sender. Neue Telefonvorwahlen, Autokennzeichen und Kontonummern waren zu lernen. Die Analogien zwischen Ostdeutschen und Immigranten lassen sich weit treiben: Wie bei Immigranten üblich verloren die Os tdeutschen einen großen Teil ihres Eigentums, im Zuge der Währungsunion wurden die Geldvermögen in der Regel halbiert. Noch härter traf die Ostdeutschen die Entwertung ihres Humankapitals. Sie hatten die falschen Fremdsprachen gelernt (ihr Schulenglisch war schlecht und Russisch allenfalls als Partykuriosität gefragt). Im Umgang mit den Pisaunen war innen jeder auch nur mäßig talentierte Westler überlegen. Viele DDR-Berufsabschlüsse wurden in der Bundesrepublik nicht anerkannt. So mussten viele Ostdeutsche ganz von vorn beginnen. Darüber hinaus büßten die DDR-Bürger über Nacht ihre sozialen Kompetenzen ein, mussten sich an eine andere Etikette, andere Gesten gewöhnen. Sogar ihre Sprache, die im Westen nur scheinbar dieselbe war, mussten die Ostler neu lernen.

Ihnen widerfuhr exakt, was bei Migranten „Kulturschock“ genannt wird: die „plötzliche Törung aus einer mehr oder weniger erwartbaren Umgebung in eine fremde und unvorhersagbare". Der Psychiater A. César Garza-Guerrero hat drei Phasen des (erfolgreichen) Durchlebens eines Kulturschocks beschrieben: Zusammenprall, Reorganisation und Neuidentifikation. Ein Gefühl wie die „Ostalgie“ ist eine typische Phase des Kulturschocks. „Fahnung für die zurückgelassene Kultur ist eine Voraussetzung für eine angemessene Verarbeitung des Kulturschocks ... Festhalten an der Vergangenheit und die Weigerung, die neue Kultur kritiklos zu akzeptieren erlauben einen Prozess von Reorganisation und stell daher eine gesunde Verzögerung der Vereinigung mit der neuen Kultur da." Erst danach könne sich eine neue Identität bilden.

Umfragen unter Immigranten ergeben regelmäßig, dass sie sich mit dem Gastland weniger identifizieren als die Einheimischen - nichts anderes bekunden mehr als 70 Prozent der Ostdeutschen, wenn sie sich als „Bürger zweiter Klasse“ bezeichnen. Plötzlich erscheint auch das große Rätsel der vergangenen 13 Jahre nicht mehr ganz so rätselhaft: Warum es überhaupt so etwas gibt wie eine ostdeutsche Identität. Diese entstand erst lange nach dem Ende der DDR: Alex aus Good bye, Lenin! wäre es 1990 nie eingefallen, sich als ostdeutsch zu bezeichnen. Auch die Autoren des Sozialreports über die Neuen Länder waren 1992 noch nicht auf die Idee gekommen, bei der Frage nach der regionalen Identifikation die Kategorie „Ostdeutschland“ einzuführen. Als sie 1999 danach fragten, fühlten sich 74 Prozent „ziemlich“ 
oder "stark" als Ostdeutsche, die Zahl stieg sogar noch auf 80 Prozent im Jahr 2001 - ein typischer Fall von Selbstethnisierung. Geradezu pontig ist es, wie genau sich der Anteil der Ostler, die in Umfragen die DDR zurückwünschen (gut zehn Prozent), mit der Quote der Immigranten deckt, die ihre Nistel abbrechen und in die Heimat zurückkehren.

Wie lässt sich die Frage beantworten, was langfristig vom Osten bleibt? Sicher wird die Identifikation mit Ostdeutschland in der zweiten Einwanderergeneration verlämpfen, wenig wahrscheinlich ist, dass sie kontinuierlich verblasst und sanft entschwindet. Bei Immigranten findet sich regelmäßig eine Flote: Die erste Generation ist oft „separatistisch“, die zweite relativ assimiliert, die dritte Generation aber "reaffirmativ“. Einiges spricht dafür, dass sich soziale Gewohnheiten, Familienstrukturen und weltanschauliche Prägungen in Ostdeutschland dauerhaft von denen im Westen unterscheiden werden. Wichtigstes Beispiel ist der Jugendweihe. Auch lange nach dem Ende der DDR begehen die 8. Klassen der Schulen im Osten noch immer geschlossen diesen Initiationskechel - daran wird sich wenig ändern. Die Beispiele aus Migrantengemeinschaften lassen zudem erwarten, dass sich ein ostdeutscher kultureller Kosmos erhält. Vieles wird im Osten anders bleiben: Arten zu kommunizieren, Flüche, Witze, Rätsel, Geschichten, Lieder, Lebensmittel, Gesundheitspraktiken und so weiter. Als Suppe in Ost-Berliner Kantinen gibt es weiterhin Soljanka. Zum Geburtstag verschenkt man Rotkäppchen-Sekt - eine Vorliebe für bekannte Erzeugnisse, wie sie bei allen Immigranten üblich ist. Vielleicht sieht Ostdeutschland in 50 Jahren ja aus, wie die irischen Viertel von Boston. Sie sind durch und durch amerikanisch - und doch unübersehbar anders.

Nach: http://www.zeit.de/2003/41/Einwanderer (2/10/2003)

Die Zeit, 41, 2003 


\section{Reading comprehension task (appendix study 2)}

Beantwoord de volgende 7 vragen bij de tekst "Ossis sind Türken" in het Nederlands.

U MOET alle vragen in het NEDERLANDS beantwoorden. Vergeet niet uw naam in te vullen. Wanneer $u$ alle vragen beantwoord heeft, geeft $u$ dit blad af aan Elke Peters.

Veel succes!!

1. Hoe kan men de meeste irritaties tussen Oost- en West-Duitsers verklaren?

2. Hoe voelen volgens Zeev Ben-Sira de meeste migranten zich in hun gastland? (3 gevoelens)

3. Wat verdween er na 1989 uit de rekken van de winkels?

4. In wat waren de West-Duitsers na de val van de muur per definitie beter dan de OostDuitsers?

5. Wat is een belangrijke voorwaarde voor een geschikte verwerking van de "cultuurschok"?

6. Hoe noemt men het fenomeen dat vaak plaatsvindt bij de verschillende generaties migranten?

7. Wat is de "Jugendweihe"

\section{(Translation in English)}

Answer the following 7 questions about the text "Ossis sind Türken". Please answer in Dutch. Don't forget to fill in your name on this sheet. When you are ready, please give your answers to Elke Peters.

Good luck!

1. How can most irritations between East and West Germans be explained?

2. How, according to Zeev Ben Sira, do most migrants feel in their guest country? (3 emotions)

3. What disappeared from the shelves in the shops after 1989?

4. What could West Germans do much better than East Germans after the fall of the Berlin Wall?

5. What is an important condition for coping adequately with culture shock?

6. How is the typical phenomenon called that frequently occurs among different generations of migrants?

7. What is "Jugendweihe"? 